\title{
Identidades femininas indígenas em movimento na poética de Eliane Potiguara
}

\section{Moving indigenous female identities in the poetic of Eliane Potiguara}

Professor do Núcleo de Literatura do Instituto de Letras e Linguística (ILEEL) e do Programa de Pós-graduação em Estudos Literários (PPLET) na Universidade Federal de Uberlândia (UFU) hitt:://orcid.org/0000-0001-9305-9519 mail: carlosaug.melo@gmail.com Doutoranda pelo Programa de Pós-graduaçâa mail: hrosacosta@yahoo.combrom

\author{
Carlos Augusto de Melo \\ Heliene Rosa da Costa²
}

RESUMO: Neste artigo, busca-se compreender de que forma o processo diaspórico em território brasileiro interfere na constituição identitária, sobretudo feminina, dos povos originários, a partir da leitura e análise crítico-literária do livro Metade Cara, Metade Máscara (2004), da precursora escritora indígena brasileira Eliane Potiguara. Sob essa mesma perspectiva analítica, propõe-se investigar também as complexas implicações dessas movimentações migratórias forçadas nas dinâmicas de violência e de silenciamento das vozes e das subjetividades indígenas. Na poética dessa escritora, as identidades têm sustentação na prática da afirmação da memória e conhecimentos ancestrais, como expressão das subjetividades, principalmente femininas, de diferentes etnias, constituindo-se lugares de conflitos e de materialização do entrelugar das vozes indígenas. Este é um texto que, muitas vezes, apoiado nas perspectivas teóricas dos Estudos Culturais, envolve uma metodologia de análise de caráter qualitativo e bibliográfico. Por fim, vale dizer que este trabalho dialoga com importantes conceitos teórico-metodológicos, recorrentes nas discussões contemporâneas dos Estudos Culturais, como os de diáspora, de desterritorialização, de transculturação, de poética de movimento, à luz dos textos de Stuart Hall, Bhabha, Ette, Ortiz, entre outros.

Palavras-chave: Literatura indígena; Identidade feminina; Eliane Potiguara; Diáspora indígena.

ABSTRACT: In this article, we seek to understand, from reading some texts of the work Metade Cara, Metade Máscara (2004), by Eliane Potiguara what form(s) the indigenous separation in brazilian territory interfere in the constitution of these people, especially in the female identity. At the same time, we investigated characteristics of the literature of indigenous authorship, based in the author's poetics, seeing the implication of these forced migrations and yours violence of dynamics and the silencing of indigenous voice and subjectivities. Therefore, we veriefied that the identity is supported by the memory and the ancestral knowledges, besides that we realized that there are aspects of poetic-literary production that appear linked to the movement of these people, motivated by the invasions of the indigenous territories. Besides that, the literature produced by the indigenous intellectuals, as an expression of the subjectivity of the different ethnic groups, become a place of conflicts and the materialization of the indigenous voices, that become this literature an important instrument to the expression and the fortification of yours subjectivities. This is a text that, sometimes supported by the perspective of Cultural Studies, involves a qualitative and bibliographic methodology. Finally, it is worth mentioning that this analytical work is in dialogue with important theoretical and methodological concepts, recurrent in the discussions of Cultural Studies, such as diaspora, deterritorialization, transculturation, poetics of movement, according to the works of Stuart Hall, Bhabha, Ette, Ortiz

Keywords: Literature of indigenous; Female identity; Eliane Potiguara; Indigenous separation. 


\section{Palavras introdutórias}

literatura é lugar de travessias no qual se transitam as mais diferentes subjetividades. Em sua materialidade linguística, revelam-se vozes e modos em movimento, segundo a perspectiva de Ottmar Ette (2016), de existência e de percepção da realidade bastante distintos em sua paradoxal complexidade e singularidade. Ou seja, literatura é "um saber em movimento, cuja estrutura multilógica possui significativa importância para a sobrevivência do mundo do século XXI e o desafio de garantir a convivência na paz e na diferença" (ETTE, 2016, p. 195).

Nessa perspectiva, a literatura de autoria indígena no Brasil, como manifestação de um grupo social violentado e silenciado por séculos, problematiza, em constantes movimentos, as diásporas dos múltiplos povos originários brasileiros, cujos deslocamentos transculturais - impulsionados ao longo da história a partir da dominação europeia pelos processos de colonização e de neocolonização - desestabiliza(ra)m as identidades dentro e fora de suas comunidades. Entendem-se, aqui, esses processos diaspóricos relacionados aos deslocamentos migratórios forçados de indivíduos, cujas consequências são os devastadores sentimentos de desenraizamento, de silenciamento, de exclusão, de não pertencimento e de constantes enfrentamentos identitários pela contingência de se viver em um entrelugar e de se perceber como o "outro". Nesse sentido, as diásporas constituem subjetividades num espaço cultural intersticial que, nas palavras de Homi K. Bhabha (1998), é o "espaço do além" onde coexistem o passado e o presente.

As diásporas dos indígenas brasileiros caracterizam-se pelas migrações forçadas, nos mais diversos espaços geográficos nacionais, em razão da colonização, da neocolonização, das invasões e disputas territoriais, do extrativismo, do agronegócio, entre outros aspectos. Diferentemente das movências voluntárias, constitutivas das dinâmicas de sobrevivência sustentável desses povos, as diásporas forçadas impulsionam a desterritorialização ${ }^{1}$ e o afastamento das tradições cultivadas nas florestas, provocando o empobrecimento material e espiritual dos nativos deslocados, o que afeta negativamente suas subjetividades identitárias e abala as noções de pertencimento e de autoimagem. Essas questões ocasionam um verdadeiro ataque aos direitos fundamentais dos povos originários que sofrem irreversíveis fragmentações em suas identidades.

As recentes produções literárias escritas dos intelectuais indígenas que abrem importante espaço para as mais variadas expressões das vozes e das subjetividades desses povos possibilitam a percepção desse fenômeno, pois seus textos carregam explícita ou implicitamente as marcas das violências sofridas pelos movimentos diaspóricos. Assim, têm-se textos literários com características muito específicas, atreladas às dinâmicas sociais, culturais e espirituais que caracterizam os diversos grupos indígenas no Brasil.

Em artigo a respeito dos povos originários que habitam o vale do Rio Doce, em Minas Gerais, o historiador Lamas (2012, p. 228) esclarece que "a diáspora indígena foi mais do que uma mera troca de lugar, pois foi forjada por lutas sangrentas que violentavam não somente o próprio corpo indígena, como também sua forma de produção cultural." o pesquisador examina em sua pesquisa as múltiplas formas de enfrentamento engendradas por esses indígenas, popularmente conhecidos como Botocudos, ao avanço dos invasores naquela região, em razão da expansão do ciclo das minerações.

Em sua obra Metade Cara, Metade Máscara (2004), a escritora indígena brasileira Eliane Potiguara traz à tona essas problemáticas em torno das movimentações das diásporas e ressalta a ausência de políticas efetivas

${ }^{1}$ O conceito de desterritorialização está relacionado ao produto das invasões aos territórios indígenas nos contextos coloniais e pós-coloniais que provocaram movimentos migratórios forçados, de modo nos contar a organização de muitas comunidades indí́ a esfacelar a organização de muitas comunidades indígenas e forçar o deslocamento de contingentes huma 
na contenção do êxodo nas comunidades indígenas. Ela evidencia o posicionamento de seu povo e aponta para as medidas necessárias para a resolução desses conflitos:

Povos indígenas querem viver dentro do equilíbrio e dar seu testemunho de uma convivência pacífica e não serem vistos na mídia empunhando bordunas ou armas. Eu clamo aos governantes e empresários: "Reconheçam os Povos Indígenas como os primeiros povos desta terra e sem paternalismos, entreguem as terras que são de seus ancestrais, numa medida de reconhecimento, de compensação e restauração da dignidade indígena deste país" (POTIGUARA, 2004, p. 96).

No contexto dessas discussões, neste artigo, buscamos compreender, a partir da leitura de alguns textos da intrigante obra Metade Cara, Metade Máscara (2004), de Eliane Potiguara, de que forma esses processos diaspóricos interferem na constituição da identidade indígena, sobretudo da identidade feminina. Propõe-se, também, refletir sobre as implicações dessas movimentações migratórias forçadas nas dinâmicas de violência e de silenciamento das vozes e das subjetividades indígenas.

Antes de se iniciar essas reflexões, impõe-se a necessidade de apresentar quem é Eliane Potiguara e qual é o seu lugar no contexto das vozes literárias indígenas escritas na história da literatura brasileira.

\section{Sobre Eliane Potiguara (1950 - )}

A escritora ${ }^{2}$, da etnia indígena potiguara, é intelectual de identidade híbrida: descende do povo Potiguara, do litoral da Paraíba, entretanto, nasceu e fixou residência na cidade do Rio de Janeiro. Apesar de ser de uma

\footnotetext{
2 É possível conseguir informações biobibliográficas no site de Eliane Potiguara: <http://www. elianepotiguara.org.br/>.
}

família bastante humilde, conseguiu graduar-se em Letras, prosseguiu na carreira docente e se enveredou pelos caminhos da literatura, vindo a ser reconhecida como uma das principais precursoras escritoras da literatura de autoria indígena no Brasil.

Baluarte nas lutas pelos direitos dos povos originários, a intelectual é porta-voz das mulheres em favor das quais criou e administra o Grupo Mulher - Educação Indígena e Rede de Comunicação Indígena (Grumin), caracterizado como um espaço virtual, público e democrático, aberto para denúncias, notícias, notas, releases e matérias jornalísticas sobre violação dos direitos humanos desses povos. Originalmente criado para favorecer a educação e a inserção social das mulheres indígenas, estabeleceu-se como mecanismo de luta em prol dos direitos dos povos indígenas, cujas demandas envolvem diversos temas: terra, territórios, trabalho, desenvolvimento, saúde, educação, questões étnicas e de gênero. Além disso, tem-se constituído como importante meio para divulgação da literatura e demais artes produzidas pelos intelectuais indígenas brasileiros.

Em artigo publicado no Suplemento Cultural do Diário Oficial do Estado de Pernambuco, em junho de 2018, o pesquisador e professor universitário Pedro Mandagará indica o poema "Identidade Indígena", de autoria da escritora Eliane Potiguara, como um dos marcos iniciais da produção literária de autoria indígena no Brasil:

Um possível começo para a escrita de autoria indígena está presente em um conjunto de cartas diplomáticas em tupi escritas por líderes indígenas como Felipe Camarão e Pedro Poty, de lados opostos da guerra entre portugueses e holandeses no Brasil colonial. Depois disso, houve um imenso hiato em que alguns autores foram descendentes de indígenas - Gonçalves Dias, por exemplo -, mas não se afirmaram como tal. Salvo engano, a autoria indígena brasileira de literatura escrita despontou entre o final dos anos 1970 e início dos 1980, tendo como um dos marcos o poema Identidade indígena, de Eliane Potiguara, escrito, segundo a autora em 1975 (MANDAGARÁ, 2018, s/p.). 
Além de alguns poemas e outros textos publicados em ambientes virtuais e no jornal do Grumin, a autora publicou os livros: A Terra é a Mãe do Índio (1989); Akajutibiró: Terra do Índio Potiguara (1994); Metade Cara, Metade Máscara (1ae ed. 2004; 2ª e 3ª ed. 2018); O Sol do Pensamento (2005); o Coco que guardava a noite (2012); O Pássaro Encantado (2014); A Cura da Terra (2015). Militante das causas indígenas, ela trabalhou pela Declaração Universal dos Direitos Indígenas, na ONU, em Genebra, e recebeu prêmios como o PEN CLUB da Inglaterra e o Fundo Livre de Expressão, nos Estados Unidos da América.

Potiguara é engajada nas lutas do seu povo e cumpre intensa agenda de viagens pelo Brasil e pelo exterior, participando de fóruns, debates, eventos literários, ministrando cursos, conferências, palestras e contando histórias. Suas produções literárias têm sido objeto de pesquisas e artigos no meio acadêmico, em âmbito nacional e internacional.

\section{Sobre Metade Cara, Metade Máscara}

A primeira edição do livro Metade Cara, Metade Máscara, lançada em 2004, compõe a série "Visões Indígenas" e tem o selo do Instituto Indígena Brasileiro para Propriedade Intelectual (Inbrapi). Teve segunda e terceira edições, atualizadas e publicadas, respectivamente, em 2018, pelas editoras DM Projetos Especiais e Grumin. Nele, revela-se uma escrita literária que mescla diferentes gêneros textuais. Paralelamente, a autora intercala poemas, relatos e artigos, valendo-se de poesia, prosa poética, contação de histórias e relatos para a materialização do livro. Contundente e de intensa força poética, o livro surpreende o leitor e intriga intelectuais e pesquisadores. A esse respeito, registramos um esforço de categorização da obra, em artigo científico, cuja articulista afirma que Eliane Potiguara publicou: “[...] uma obra inclassificável, Metade Cara, Metade Máscara, que contribuiu muito para a visibilidade do fenômeno cultural da chegada recente da literatura indígena ao mercado editorial brasileiro." (OLIVIERIGODET, 2017, p. 103).

De forma correlata, o escritor português radicado na Angola, Leonel Cosme, registrou suas impressões a respeito da leitura dessa obra em que poesia, ficção e realidade se interpenetram de forma a produzir múltiplos efeitos de sentido e a intensificar a carga semântica de seus conteúdos e a impactar o leitor magistralmente. Nas palavras dele:

Tenho de começar por dizer que a minha memória não registra, depois da Renúncia Impossível, do maior poeta negro angolano, Agostinho Neto, outro livro tão perturbador como é Metade cara, metade máscara, da escritora e poeta índia brasileira Eliane Potiguara, a cuja apresentação assisti, na cidade do Porto - Portugal, a 13 de Novembro de 2010 (COSME, 2015, p. 73)

Em seu artigo, o autor analisa poéticas de escritores africanos, confrontando-as com alguns aspectos da escrita indígena de Eliane Potiguara, ao mesmo tempo em que discorre sobre semelhanças em relação às diversidades étnicas e culturais existentes no Brasil e em alguns países da África. Leonel Cosme ressalta, em sua leitura de Metade Cara, Metade Máscara, características como a recuperação da ancestralidade e a busca das identidades, além de salientar que, na tessitura poética da obra, há as percepções e as subjetividades da autora, pois ela é "uma mensageira talvez só (mal) imaginada no recôndito das selvas brasileiras". Cosme (2015) categoriza Metade Cara, Metade Máscara como um livro 'perturbador'.

Na constituição dessa obra, a saga poética de Jurupiranga e Cunhataí ocupa posição central. Trata-se de abordar as movências humanas no interior do Brasil, a partir da trajetória de um casal que representa simbolicamente as famílias indígenas brasileiras. Os consortes, separados no início da trama, 
passam por diversas (des)aventuras, em cenário e tempo míticos, desde o início do processo da colonização europeia em solo brasileiro.

Com essa trajetória, as migrações indígenas forçadas são representadas no poema em meio ao protagonismo de Cunhataí, a heroína mítica que luta para reencontrar o seu amado, recuperar suas terras e reconstituir a família. Entretanto, chora a solidão e a ausência do esposo, a quem busca incessantemente. A saudade e o lamento da mulher errante saltam nos versos de seu "Cântico da Distância":

O que quero dizer são loucuras assim...

São delírios da noite, pesadelos sem fim

São absurdos desejos embebedando a solidão

Pois perdi o caminho e sofri o amanhã.

Agora o que faço: só penso intranquila

A tua figura diante de mim

Parado no vento, feito imagem de santo

Que nem posso tocar...

Que nem posso falar...

Porque és feito pras deusas,

Completamente impossível

Impossível de olhar...

Impossível de amar...

E as minhas mãos trêmulas e tímidas

Procuram as tuas

E estás tão distante no tempo, no espaço

Que faço loucuras e grito e procuro.

Mas paro!

E quero apagar da minha memória

Tua imagem de homem

Cantando a história

Porque és forte, por ser macho guerreiro

Valente lanceiro

Gritando a vitória.

E só porque existes

Nem pedes licença

E me invades a mente.
O que quero dizer são loucuras enfim...

Loucuras escondidas, sentidas, doídas

Tanta loucura que não quero mais pensar em ti.

[...]

(POTIGUARA, 2004, p. 70).

Numa representação poética do desejo de (re)união das famílias desenraizadas de seus territórios primitivos por força das transformações impostas, no Brasil, pelos processos de colonização, neocolonização, expansão industrial, expansão extrativista e globalização, a autora reflete sobre o fardo dessas mulheres, sua solidão e sua luta pela recuperação da dignidade da família e das comunidades, numa tentativa de resgate de sua integridade física, moral, espiritual, étnica e cultural. Uma tarefa que se prolonga no tempo e no espaço e encontra correspondência, hoje, no campo e na cidade, no movimento organizado de lutas das mulheres indígenas, das quais Eliane Potiguara é uma das protagonistas, cujos propósitos guardam semelhanças marcantes com a saga da guerreira indígena Cunhataí.

Ainda nas palavras da autora:

Na realidade, a simbologia de Cunhataí demonstra o compromisso que ela tem com todas as mulheres indígenas do Brasil. Sua dor, sua insatisfação e a consciência de mulher é a mesma trazida pelas mulheres guerreiras atuais que ora se organizam. [...] Cunhataí reconhece que as bases de suas tradições indígenas só serão preservadas quando sua família estiver unida, física e moralmente (POTIGUARA, 2004, p. 69-70).

Obra prima da literatura de autoria indígena brasileira, sua leitura revela que as identidades indígenas se manifestam de modos variados e tem como sustentação a memória e os conhecimentos ancestrais transmitidos pela avó da narradora, por meio da contação de histórias, desde a infância da poeta. 
O livro coloca em evidência o universo feminino, com textos que abordam: amor, família, pertencimento, violência, identidade e direitos humanos, entre outros temas. Nas palavras de Graça Graúna:

Metade Cara, Metade Máscara é um espaço de plurissignificação que nos leva, de imediato, a uma reflexão acerca de sua estreita relação entre poesia e história, entre o real e o imaginário, o sagrado e o profano, o individual e o coletivo e outros elementos caracterizadores da obra literária. Nesse campo de multissignificação, estabelece-se o caráter emblemático que vem do próprio título do livro, como alusão à identidade (GRAÚNA, 2013, p. 98).

A pluralidade e o status de idiossincrasia da poética de Potiguara possibilitam o estudo sistemático da identidade e da ancestralidade. A(s) voze(s) feminina(s) se reafirma(m) na dinâmica do discurso poético como forma de resistência e de asseveração da cultura e da subjetividade dos povos indígenas, refletindo, sobretudo, as complexidades dessas vidas em trânsito em constantes conflitos com o "outro".

Desse modo, a narrativa oferece relevo ao tensionamento marcado pelas vivências dos povos ressurgidos - "indígenas desaldeados e indígenas descendentes" (POTIGUARA, 2004, p.94). A autora se indigna contra a forma como seu povo é desumanizado a partir das relações assimétricas de poder no contexto urbano. Em uma das seções do capítulo 4, ela relata: "Vi um indiozinho escorrendo pelo bueiro. A metade de seu corpo superior debruçava-se sobre o meio-fio da rua e a outra parte jazia cansada, escorrendo pelo esgoto urbano." (POTIGUARA, 2004, p. 93). A subjetividade feminina ferida, em sensíveis tons maternos, pela visão do "indiozinho urbano" é materializada na superfície textual em denúncia contra a negligência do governo e a indiferença da sociedade.

$\mathrm{Na}$ voz de Potiguara, as condições insalubres de sobrevivência enfrentadas, cotidianamente, nas grandes cidades, pelos povos indígenas que sofreram e ainda sofrem as consequências da diáspora são enfatizadas:
O último censo do IBGE registrou um aumento da população indígena, considerando os indígenas desaldeados e os indígenas-descendentes. Isso é um primeiro passo. Mas, enquanto isso, o indiozinho continuava lá sucumbindo às lágrimas. Seu corpo sujo e magro amoldava-se às formas do paralelepípedo. Sua cabeça reclinava sobre o chão imundo e seus pés mostravam os ossos aos "abutres". Eu nunca vira uma cena como essa. Nessa noite eu não dormi. Nem na Índia eu vira cena tão agressiva à minha ética. [...] Toda essa cena contrastava-se com a propaganda de arte indígena que nesse momento fazia sucesso em uma exposição citadina que corre o Brasil: "arte milenar indígena não morre!"... Mas as pessoas indígenas morrem pela falta de uma posição governamental que faça exercer os direitos indígenas nesse país. 0 indígena precisa sair das paredes, dos museus, das salas de exposição!" (POTIGUARA, 2004, p. 94).

A justaposição da imagem do corpo da criança no chão e o cartaz da propaganda de arte indígena evidenciam a face grotesca da dicotomia "real × idealizado" que permeia o imaginário coletivo acerca das populações indígenas no Brasil. Durante séculos, essa visão foi retroalimentada por produções artísticas - com destaque para as obras literárias - e pela teoria da literatura em inequívoca opção histórica pela visão eurocêntrica.

Na esteira dessas considerações, Moita Lopes esclarece:

A identidade social é vista como inerente às pessoas e não como emergindo de práticas discursivas nas quais as pessoas se engajam no discurso ao construírem a realidade social e a si mesmas, em circunstâncias sóciohistóricas particulares. A diferença é entendida como intrínseca às pessoas de forma que as restrições discursivas que constroem as pessoas de uma maneira ou de outra são naturalizadas (MOITA LOPES, 2002, p. 52).

A naturalização referida pelo autor explicita o foco da questão: tratase de transferir para a vítima a responsabilidade pela sua condição, assim, estado e sociedade se eximem do dever de buscar soluções para esse problema. O discurso oficial legitima essas estratégias de distorção do real, por meio da naturalização das diferenças. A despersonalização dos 
povos originários no espaço urbano constitui subterfúgio para ofuscar desigualdades e violências impostas pelo sistema e potencializadas pelo êxodo dessas populações. Para tanto, investe-se na idealização da imagem do indígena como produto da arte e nega-se a real existência do indivíduo massacrado pelos desnivelamentos no espaço urbano. Nessa experiência, as populações indígenas enfrentam, nos centros urbanos, a diluição da noção de subjetividade e a negação da visibilidade e do potencial de expressão identitária. A afirmação de sua existência material, nos dados do recenseamento, já é considerada uma vitória por essa parcela da população.

Em alguns contextos, a literatura também contribui para a efetivação desse processo de marginalização dos indígenas brasileiros. Há distorções escamoteadoras da realidade, caracterizadas pela exclusão e pelo silenciamento das vozes e das subjetividades dessa parcela da população. Consequentemente, a proeminência desses traços na produção literária interfere na constituição e na percepção da própria identidade desses indivíduos.

\section{Sobre diásporas e identidades indígenas em movimento}

Subvertendo a ordem hegemônica, os escritores indígenas utilizam-se da literatura como instrumento de resistência. Ela se torna parte integrante da luta pela conquista de direitos e de reconhecimento da contribuição cultural dos intelectuais indígenas. Além disso, constitui expressão contra as injustiças e os ataques aos direitos fundamentais, tanto nas florestas como nas cidades.

A literatura indígena atua em favor da preservação da memória, da identidade e da ancestralidade das diversas comunidades indígenas brasileiras, aspectos esses que são essenciais para a compreensão da complexidade do processo de (trans)formação identitária dos povos originários brasileiros no contexto das diásporas internas provocadas pelas invasões dos territórios indígenas. A esse respeito, Munduruku pondera:

Nesse quadro de diferentes situações, povos indígenas inteiros têm sofrido as consequências de viver em contato permanente com uma sociedade que lhes prende em conceitos que os tornam menores e marginalizados. A isso inclui a negação da identidade cultural. Se, por um lado, manterse indígena é condição fundamental para o reconhecimento étnico - pois assim a sociedade complexa pode manipulá-lo -, aprender a conviver com a sociedade em igual condição é considerado um abandono de identidade. [...] Ao pertencer ao mundo globalizado, perco minha afirmação étnica. Essa forma de pensar tem ocasionado sérias crises de identidade em nosso meio (MUNDURUKU, 2010, p.67).

Nessa dinâmica, intrínseca à lógica ocidental de negação das subjetividades dos povos indígenas, que perdura por séculos, há a imposição do ponto de vista europeu, representado na história oficial. Percebe-se, dessa forma, a face perversa do processo de transculturação ${ }^{3}$ em que o indivíduo, espoliado em sua identidade primitiva, é expropriado em seu direito à cidadania, ao mesmo tempo em que, em trânsito, perde o reconhecimento de seu povo por não pertencer mais à aldeia. Ironicamente, a sociedade urbana não o acolhe, restando ao diferente a única opção de ocupar um entrelugar, duplamente marginalizado.

Uma vez integrada como parte desses indivíduos, a narrativa do deslocamento na poética de Eliane Potiguara registra um movimento diaspórico duplo: da cidade para o campo, a luta pelo resgate de sua identidade indígena; e do campo para a cidade, outra luta pela comprovação

30 conceito de transculturação está relacionado às variadas possibilidades de construções de identidades, determinadas pelas relaç̃̃es entre povos pertencentes às diferentes culturas. Apoia-se no conceito de Ortiz (1983), cuja reflexão aponta para as transformaç̃̃es das culturas que, quando entram conceito de Ortiz (1983), cuja reflexão aponta para as transformaçoes das culturas que, quando entram em contato por conta da dinâmica da diáspora, formam outras novas culturas, sem impedir a interação entre passado e presente. Nesse sentido, no contexto das produçôes dos intelectuais indigenas em 
dessa identidade, do ponto de vista legal. Além disso, há ainda esforços por ela empreendidos para ser aceita em sua aldeia ancestral no litoral paraibano. Nesse aspecto, o artigo de Pedro Mandagará sobre a escrita das mulheres indígenas é bastante esclarecedor:

A reiteração dessa identidade - ser potiguara, ser indígena - perpassa toda a poética da autora. Lendo as memórias que pontuam o texto em prosa de Metade cara, metade máscara, percebe-se o conflito de crescer e viver no Rio de Janeiro e se descobrir indígena desaldeada. Em certo momento, a indianidade da autora causa polêmicas com outros potiguaras, que não lhe querem reconhecer o direito à ancestralidade [...]. Seu pertencimento acaba sendo reconhecido judicialmente por meio de documentos e testemunhos, mas as marcas do conflito ressurgem em diversos poemas do livro (MANDAGARÁ, 2018, s/p.).

No escopo dessas considerações, a reafirmação da tradição e da memória torna-se ato de resistência cultural por promover o fortalecimento dos indivíduos e de suas comunidades e possibilitar tanto um retorno simbólico às origens quanto o reencontro com a identidade indígena primitiva. Esse reencontrar-se com a identidade primeira - obscurecida pela mescla cultural resultante dos processos diaspóricos nos contextos colonial e global - fortalece as subjetividades e as noções de pertencimento desses indivíduos oprimidos na dinâmica das movências humanas de tal modo, que o eu-lírico evidencia sua rejeição em relação a esse sistema opressor, como podemos ler no poema "Desilusão":

A mim me choca muito esse ambiente

Essa música, essa dança

Parece que todos dizem sim.

Sim a quê?

Sim a quem?

Por que concordar tanto

Se o que se tem que dizer agora

É NÃO!
NÃO à morte da família

NÃO à perda da terra

NÃO ao fim da identidade.

(POTIGUARA, 2004, p. 64)

Segue-se um duplo questionamento: versos construídos em estrutura interrogativa direta, no quarto e quinto versos; e indireta, no sexto verso, marcam a falta de orientação lógica diante dos fatos vivenciados. 0 tom incisivo e categórico utilizado para predizer a negativa é intensificado pela grafia do advérbio em caixa alta: NÃO. Da mesma forma, a reiteração destacada do termo, nos dois últimos versos do poema, completa o ciclo das violências impostas pelo processo de desterritorialização. Essa postura ambígua e de aparente confusão do eu-lírico justifica-se pela complexidade envolvida na questão da identidade para os indígenas desaldeados.

Por outro lado, a postura do eu-lírico constitui reação às estratégias de apagamento engendradas e naturalizadas pelo aparato opressor do sistema hegemônico. Nesse sentido, o apagamento censitário é discutido pela autora Graça Graúna -intelectual indígena, escritora, poeta e professora universitária - na obra Contrapontos, ao lembrar que: "O problema do recenseamento indígena no Brasil exige uma leitura em contraposição ao censo que tem negado até então a existência dos povos ressurgidos." (GRAÚNA, 2013, p.39). Ela esclarece que as estratégias de manipulação intencional de dados explicitam o desejo, por parte de alguns órgãos institucionais, de negação da existência e do direito à cidadania para essa parcela da população.

Em contrapartida, seria ingênuo crer que o reconhecimento institucional por si só garantisse condições de existência material digna a essas populações. Assim, a escritora denuncia o engodo: a invisibilidade dos indivíduos na estrutura social urbana, o descaso do governo e a hipocrisia da sociedade que, a exemplo do que se fazia na primeira fase do período 
literário romântico, continua idealizando a figura do índio e recusando-se a reconhecer a complexidade de sua existência na modernidade tardia.

Em alguns poemas, as subjetividades, afloradas na expressão do eu-lírico, tornam evidente, do ponto de vista das comunidades originárias, o olhar de quem não se reconhece como parte da cena hostil. Essa percepção excêntrica aparece no texto "Agonia dos Pataxós", em que um espelho reflete a face deslocada e descentrada do eu-lírico. Eis o poema:

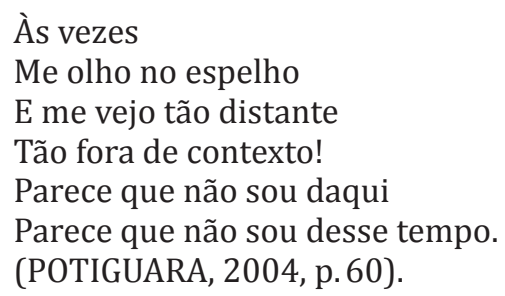

A presença do espelho, na cena lírica, revela o esfacelamento da voz poética, desfocada em um estranhamento que torna difusa a localização espacial e temporal. Nessa dinâmica, nota-se uma ruptura na percepção do eu, cujas concepções acerca da própria identidade aparecem solapadas e o deslocamento materializa-se na superfície textual por meio da modalização expressa no trecho "parece que", reiterada nos dois últimos versos.

Já a visão da imagem refletida no espelho é narrada de modo a intensificar a distância entre os "eus", que assumem o papel de agente e paciente em relação à semântica verbal. Essa fragmentação do eu-lírico imprime dupla predicação ao verbo, de forma que há um eu inscrito no real imediato, espacialmente fixado pela presença do dêitico (daqui), e outro eu que se acha deslocado e não se reconhece no tempo do agora, percebendose "fora de contexto". A partir dessa leitura, a noção de identidade é levantada e podemos discuti-la na perspectiva de Zygmunt Bauman que, em entrevista concedida ao jornalista Benedetto Vecchi, comenta a respeito desse conceito. Trata-se de reflexões tecidas a partir de sua vivência como migrante judeu polonês na Inglaterra, no contexto da "modernidade líquida". Para o autor, a experiência de estar ou sentir-se deslocado pode parecer bastante desconfortável:

Estar total ou parcialmente "deslocado" em toda parte, não estar totalmente em algum lugar (ou seja, sem restrições e embargos, sem que alguns aspectos da pessoa "se sobressaiam" e sejam vistos por outras como estranhos), pode ser uma experiência desconfortável, por vezes perturbadora. Sempre há alguma coisa a explicar, desculpar, esconder ou, pelo contrário, corajosamente ostentar, negociar, oferecer e barganhar (BAUMAN, 2005, p. 19).

Na obra de Eliane Potiguara, da mesma forma, o eu-lírico explicita a angústia e o desconforto que acompanham o sentimento de não pertencer. Nos versos do poema "Pankararu", a voz coletiva enuncia em tom paternal:

Sabe, meus filhos...

Nós somos marginais das famílias

Somos marginais das cidades

Marginais das palhoças..

E da história?

Não somos daqui

Nem de acolá..

Estamos sempre ENTRE

Entre este ou aquele

Entre isto ou aquilo

Até onde aguentaremos, meus filhos?..

(POTIGUARA, 2004, p. 60).

Nessa perspectiva, questões subjetivas acerca da percepção da própria identidade remetem a uma desconstrução e fragmentação engendradas no seio das práticas sociais excludentes, uma vez que a percepção das diferenças permeia o processo de construção identitária e pode envolver aceitação ou 
rejeição de determinados aspectos a partir de (pré)julgamentos. Assim, conforme salienta João Adalberto Campato Jr::

0 outro faz parte da construção da identidade, pois só me percebo ao perceber o outro (princípio da alteridade). 0 outro, na maior parte dos casos, constitui uma ameaça, porque, sendo diferente, coloca-nos diante de nossa incompletude, da possibilidade de estarmos errados, de, eventualmente, não sermos os naturais superiores, de nossas normas de comportamento e valores não se revestirem, nem sempre, da verdade exclusiva. Daí surgem, como defesa, os julgamentos negativos sobre o outro e, como seria de esperar, o preconceito (CAMPATO JR., 2016, p. 293).

A ameaça referida pelo autor não deve ser negligenciada, pois tem potencial para desencadear práticas que culminam com o silenciamento da voz e podem até mesmo embaralhar a percepção dos indivíduos oprimidos a respeito de suas próprias subjetividades, trata-se de um jogo sutil de acabamento da percepção de si a partir do olhar do outro.

Em contrapartida, preconceito, exclusão e, consequentemente, o apagamento das subjetividades desencadeiam reação da parte oprimida, como forma de resistência. A presença declarada desses elementos no contexto de produção da literatura de autoria indígena no Brasil constitui característica dessa vertente da produção poética e literária de forma geral e, por isso, a produção dos intelectuais indígenas do Brasil vem se consolidando como forma de luta e de resistência.

Nesse sentido, é uma literatura cuja escrita carrega a marca da indignação e da denúncia, como no texto "Sepé Tiaraju", em que o eu-lírico explicita sua revolta:

Eu sou rebelde

E faço questão de o ser

Tenho fome, tenho ódio

E não me deem uma metralhadora.

(POTIGUARA, 2004, p. 62).
Aqui, não se pode esquecer que esse pertencimento a dois mundos tão distintos - aldeia e metrópole - representa a possibilidade de um olhar diferenciado sobre questões existenciais e de inserção social. Uma vez que se trata de ocupar um entrelugar, marcado pelas vivências de indivíduos que participam, simultaneamente, de realidades e de subjetividades diversas. Refletindo sobre a questão da subjetividade, Liane Schneider afirma:

Ao pensar em subjetividades híbridas ou mestiças, é quase inevitável divagar sobre fronteiras, limites de território. Na verdade, esses sujeitos híbridos ameaçam o significado geralmente colado a essas palavras eles não podem ser seguramente definidos quanto ao pertencimento - se pertencem "aqui" ou "ali", sendo equipados para circular pelos dois lados, capazes de assumir a posição subjetiva tanto de "um" quanto do "outro" elemento envolvido, ainda que lhes seja frequentemente lembrado que o seu lugar é "lá fora" (SCHNEIDER, 2008, p. 88).

Ademais, há diversos aspectos relevantes a serem considerados quando são abordados temas como a colonização e a globalização como partes integrantes da constituição histórica das nações. Sem dúvida, a violência empregada na dominação cultural e espiritual dos primeiros habitantes de nossas terras atua como força intensificadora dos mecanismos e das estratégias de opressão. A complexidade desses processos e sua interferência na percepção identitária dos indivíduos suscita discussões a respeito das consequências da mescla cultural, em função da convivência entre povos pertencentes a culturas diferentes. A respeito desse tema e para argumentar contra o emprego do conceito de desindianização, a escritora Graça Graúna assevera:

É possível dizer - dentro da percepção indígena - que o índio não deixa de ser ele mesmo em contato com o outro (o não índio), ainda que o(a) indígena more numa cidade grande, use relógio e Jeans, ou se comunique por um celular; ainda que uma parabólica pareça, ao outro, um objeto 
estranho ou incompatível com a comunidade indígena; ainda que nos deparemos com o indígena nos caminhos da internet, em plena construção de aldeias (aparentemente) virtuais; mesmo assim, a indianidade permanece, porque o índio e/ou índia, onde quer que vá, leva dentro de si a aldeia (GRAÚNA, 2013, p. 59).

Como parte de um conjunto de práticas excludentes, não é incomum relatos de indígenas serem abordados com estranheza pelo fato de usufruírem dos bens móveis e das tecnologias modernas disponíveis nos centros urbanos. Tais ocorrências revelam, grosso modo, a existência de crenças que seria possível que os indígenas perdessem sua identidade étnica diante de determinadas práticas, hábitos e/ou comportamentos. Para se contrapor a essas convicções, Graça Graúna rejeita os termos “aculturação" e "desindianização", quando empregados para fazer referência aos processos que envolvem os povos indígenas desaldeados.

$\mathrm{Na}$ mesma direção, o caráter representativo da literatura constitui contraponto fundamental na desconstrução dessa ótica que produz e legitima o apagamento da história, da memória e da subjetividade de povos inteiros, por interesse de dominação econômica, social, espiritual e cultural. É assim que a literatura indígena brasileira se constitui como força de coesão para os diversos grupos indígenas e como resistência na luta contra os preconceitos. A produção literária soma-se às diversas outras estratégias de luta por visibilidade, por respeito e por reconhecimento do seu valor histórico, cultural e estético.

Ainda nessa perspectiva, a obra Metade Cara, Metade Máscara carreia a voz e as subjetividades dos povos indígenas, constituindo-se lugar de materialização das memórias, histórias e lutas desses povos, pelo olhar da militante intelectual potiguara e na presença poética de Cunhataí. No desenvolvimento da leitura, a jornada da heroína mítica e de seu amado se transforma em sofrimento, com a separação, a partir das invasões aos territórios indígenas. Expulsos de suas terras, os protagonistas seguem o percurso da migração.

Potiguara aponta o caráter deletério dessas movimentações para as comunidades originárias, cujas famílias desagregadas são forçadas a vivenciar a violência física, material e espiritual nos centros urbanos. Indivíduos afastados de suas origens e expropriados da relação próxima e fundamental com a natureza tornam-se melancólicos, como nos revelam os versos do poema "Migração Indígena":

No teu universo de gestos

Teus olhos são mensagens sem palavras

Tua boca ainda incandescente

Me queima o rosto na partida

E tuas mãos...

Ah! Não sei mais continuar esses cânticos

Porque a mim tudo foi roubado.

Se ainda consigo escrever alguns deles

Só é fruto mesmo da mágoa que me toma a alma

Da saudade que me mata

Da tristeza que invade todo o meu universo interno

Apesar do sorriso na face...

(POTIGUARA, 2004, p. 37-38).

Como porta-voz do povo potiguara e dos parentes indígenas de diferentes etnias e na condição de defensora dos direitos, a autora exalta a cultura e os territórios desses povos:

Desde o passado até os dias atuais, o território e a cultura indígenas têm sido as linhas-mestras de determinação para a sustentação de um povo. [...] Um território não é apenas um pedaço ou vastidão de terras. Um território traz marcas de séculos, de culturas, de tradições. É um espaço verdadeiramente ético, não é apenas um espaço físico como muitos políticos querem impor. Território é quase sinônimo de ética e dignidade. Território é vida, é biodiversidade, é um conjunto de elementos que compõem e legitimam a existência indígena. Território é cosmologia que passa inclusive pela ancestralidade (POTIGUARA, 2004, p. 105). 
Como consequência de suas concepções, a autora defende o desenvolvimento de políticas para a transformação radical e verdadeira das relações entre poder público/sociedade e as comunidades indígenas no Brasil. Nessa perspectiva, sua produção literária faz parte do armamento utilizado por ela na jornada militante empreendida em prol dos direitos e do resgate da dignidade do seu povo.

\section{Palavras finais}

$\mathrm{Na}$ tessitura de sua obra, Eliane Potiguara promove fortes reflexões em torno dos impactos das migrações involuntárias e de seus desdobramentos para as famílias indígenas vitimadas. No bojo dessas complexidades, são representadas as interferências e os impactos das diásporas nas (re)construções das identidades femininas vivenciadas forçosamente pelas mulheres da família de Eliane Potiguara: a avó, a mãe e as tias, que abandonaram o estado da Paraíba após o desaparecimento do patriarca, Chico Solon, o bisavô da escritora.

Deslocamentos dessa natureza promovem transformações na ordem social, política e cultural estabelecida e interferem nas constituições das identidades, as quais se revelam multifacetadas. O esfacelamento das identidades indígenas é, em voz narrativa e berros poéticos, denunciado, com convicção étnica, no emaranhado híbrido dos textos que constituem a obra de Eliane Potiguara em questão e a hibridização dos gêneros textuais permite conotar os traços dessas identidades complexas e multifacetadas nas diversas vozes que enunciam.

Assim, nas linhas de Metade Cara, Metade Máscara, confirma-se a presença de uma mulher indígena que, construída no contexto da diáspora dos povos originários, confirma, com determinação, sua identidade híbrida, ou seja, identidade de uma indígena, poeta, professora e militante pelas causas indígenas. É uma mulher que, na contramão da visão tradicional, colonial, etnocêntrica e misógina, mostra o domínio da escrita de um livro o qual, em uma interessante dinâmica literária, entrecruza poeticamente ficção e realidade, utopia e denúncia, indignação e esperança, prosa e verso, que surpreendem os leitores. Além disso, a(s) voze(s) feminina(s), de forças ancestrais, impõe $(\mathrm{m})$ relevo ao fato de que as consequências desses deslocamentos se fazem sentir de forma mais acentuada sobre as mulheres e as crianças, que se transformam em vítimas preferenciais dos abusos e da mendicância.

Nessa perspectiva, a mulher indígena tem seu protagonismo evocado nas ações da guerreira mítica Cunhataí que, conectada com a natureza e com os espíritos da floresta, consegue recuperar a unidade de sua família ao reencontrar Jurupiranga e retornar às terras ancestrais. Há uma reveladora característica diaspórica em que se desenha a identidade feminina atemporal, conectando o passado ancestral à contemporaneidade em uma linha ininterrupta. Ou seja, a poética de Eliane Potiguara costura-se no "cordão umbilical" que, nas palavras de Hall (2003, p. 29), "chamamos de 'tradição', cujo teste é o de sua fidelidade às origens, sua presença consciente diante de si mesma, sua 'autenticidade'".

O olhar feminino permeia e constitui o processo composicional da obra, bem como o processo de constituição da própria narradora e suas vozes poéticas - o universo feminino é motivo e tema. A temática se concretiza em torno das histórias das mulheres, aquelas que não foram contadas. É pela perspectiva feminina que o discurso de bases patriarcais é desestabilizado e se pode denunciar, por exemplo, os estupros coletivos: "Quem são vocês que podem violentar/A filha da terra/E retalhar suas entranhas?" (POTIGUARA, 2004, p. 35), numa metáfora da terra saqueada pelos invasores em busca de riquezas. Para Potiguara, todas as mulheres são manifestações vivas da mãe terra. Tanto que, na cena da barbárie colonial e pós-colonial, as invasões 
territoriais são seguidas pela posse dos corpos das mulheres, por meio dos estupros coletivos, a esterilização, o tráfico e a sedução para o trabalho semiescravo e a prostituição.

No plano textual, a linguagem oscila entre o registro formal e as marcas da oralidade, em violações intencionais das normas da língua culta, cujo emprego, na escrita, permite identificar que a rebeldia manifesta na temática da obra se repete no trato com a língua, como forma de resistência e insubordinação em relação ao sistema rígido de regras, forjado pela ótica do dominador responsável pelas migrações forçadas na história dos povos indígenas brasileiros.

Acrescente-se a isso, a predominância da oralidade como traço característico das comunidades tradicionais, nas quais a escrita se impõe como um obstáculo a ser superado, tendo em vista que os intelectuais indígenas buscam o domínio das habilidades da escrita com o intuito de se valerem da literatura como importante artefato na luta por visibilidade e por garantia de expressão. Entretanto, esses autores deixam, nos textos literários, as marcas de uma literatura indígena secular, cujas textualidades ultrapassam as barreiras da palavra e materializam-se em grafismos, desenhos, cores, pinturas corporais, rememoração dos sons do vento e das chuvas, bem como do canto dos pássaros e dos misteriosos ruídos noturnos, oriundos do interior das matas.

A partir dessas reflexões, percebe-se que o papel, o alcance e os desdobramentos da literatura de autoria indígena no Brasil devem ser analisados em perspectiva crítica e analítica, pois é por meio dessa literatura que a voz e a subjetividade de um segmento importante da sociedade brasileira têm vindo à tona para desmistificar a identidade do nosso povo, revelando-a, definitivamente, como produto da diferença. Com base na pertinência das informações e dos pressupostos teóricos supracitados, conclui-se que há uma urgente necessidade de se revisar aspectos das teorizações acerca da literatura brasileira e do seu lugar no contexto de representação do que vem a ser a produção literária nacional nos moldes da complexidade e da heterogeneidade da nossa sociedade. Faz-se necessário, também, considerar a pertinência das diferenças e das incoerências que lhe são historicamente constitutivas para dinamizar os processos de leitura e interpretação dos textos produzidos por escritores indígenas.

\section{Referências}

BAUMAN, Zygmunt. Identidade: entrevista a Benedetto Vecchi. Tradução de Carlos Alberto Medeiros. Rio de Janeiro: Jorge Zahar Ed., 2005.

BHABHA, H. Locations of Culture. In: RICHTER, D. H. The Critical Tradition. Boston: Bedford Books, 1998.

CAMPATO JR., João Adalberto. Manual de literaturas de língua portuguesa: Portugal, Brasil, África Lusófona e Timor Leste. Curitiba: CRV, 2016.

COSME, Leonel. As impossíveis renúncias de Agostinho Neto e Eliane Potiguara. Revista ECOS, v. 11, n. 2, 2015. Disponível em: http://periodicos.unemat.br/index.php/ecos/ article/view/715. Acesso em: 26 set. 2016.

ETTE, Ottmar. Pensar o futuro: a poética do movimento nos Estudos. Alea, Rio de Janeiro, v. 18, n. 2, p.192-209, maio-ago. 2016. DOI: http://dx.doi.org/10.1590/1517106X/182-192

HALL, Stuart. Pensando a Diáspora: reflexões sobre a terra no exterior. In: Da Diáspora: identidades e mediações culturais (Org. Liv Sovik). Belo Horizonte: Editora UFMG, Brasília: Representação da UNESCO no Brasil, 2003.

GRAÚNA, Graça. Contrapontos da literatura indígena contemporânea no Brasil. Belo Horizonte: Mazza Edições, 2013.

LAMAS, Fernando. Os indígenas de Minas Gerais: guerra, conquista da terra, colonização e deslocamentos. Projeto História. São Paulo, v. 44, p. 227-257, 2012.

MANDAGARÁ, Pedro. Uma forma de ver as literaturas das mulheres indígenas. Suplemento Cultural do Diário Oficial do Estado de Pernambuco. Publicado em 06 de junho de 2018. Disponível em: http://www.suplementopernambuco.com.br/artigos/2100uma-forma-de-ver-as-literaturas-das-mulheres. Acesso em: 08 jun. 2018. 
MOITA LOPES, Luis Paulo da. Identidades fragmentadas: a construção discursiva de raça, gênero e sexualidade em sala de aula. Campinas: Mercado das Letras, 2002.

MUNDURUKU, Daniel. Mundurukando. São Paulo: Ed. do Autor, 2010.

OLIVIERI-GODET, Rita. Graça Graúna: a poesia como estratégia de sobrevivência. Revista Interfaces Brasil-Canadá. Florianópolis/Pelotas/São Paulo, v. 17, n. 3, 2017. Disponível em: <https://periodicos.ufpel.edu.br/ojs2/index.php/interfaces/article/download/>. Acesso em: 14 abr. 2018. DOI: http://dx.doi.org/10.15210/interfaces.v17i3.12569

ORTIZ, F. Contrapunteo cubano del tabaco y del azúcar. La Habana: Editorial de Ciencias Sociales, 1983.

POTIGUARA, Eliane. Metade cara, metade máscara. São Paulo: Global, 2004.

POTIGUARA, Eliane. Metade cara, metade máscara. 2 ed. Lorena: DM Projetos Especiais, 2018.

POTIGUARA, Eliane. Metade Cara, Metade Máscara. 3. ed. Rio de Janeiro: Grumin, 2018.

SCHNEIDER, Liane. Escritoras indígenas e a literatura contemporânea dos EUA. João Pessoa: Ideia, 2008.

Recebido em 28/06/2018. 